\title{
Methods for coastal monitoring and erosion risk assessment: two Portuguese case studies
}

\author{
A. Bio ${ }^{\circledR,}{ }^{1}$; L. Bastos ${ }^{1,2}$; H. Granja ${ }^{1,3}$; J.L.S. Pinho ${ }^{4}$; J.A. Gonçalves ${ }^{1,2}$; \\ R. Henriques ${ }^{3,5}$; S. Madeira ${ }^{1,6}$; A. Magalhães ${ }^{1,7}$; D. Rodrigues ${ }^{4}$
}

\begin{abstract}
Coastal zones are naturally dynamic and mobile systems exposed to natural factors (river flows, waves and storms) as well as human interventions that continuously reshape their morphology. Erosion phenomena related to extreme weather events and sediment scarcity are common, threatening buildings and infrastructures, as well as beaches, ecosystems and valuable wetland; conditions that pose challenges to coastal security and defence. Regular monitoring of coastal areas, assessment of their morphodynamics and identification of the processes influencing sediment transport are thus increasingly important for a better understanding of changes and evolutionary trends in coastal systems. This demands a multi-disciplinary approach involving researchers with expertise in coastal processes and state- of-the-art observation technologies.

In this paper state-of-the-art surveying methods for an efficient quantification of changes in coastal environments are described and evaluated, and two NW-Portuguese case studies are presented. Survey methods included: topographic surveys based on terrestrial videogrammetric mobile mapping and aerial photogrammetry; sub-tidal bathymetry with sonar imagery using an Autonomous Surface Vehicle (ASV); as well as field observations, with sediment sampling and beach characterisation. In the first case study, erosion/accretion patterns in the Douro estuary sand spit were analysed, considering its breakwater, river flow, wave and wind effects. Prior to the construction of a detached breakwater, the spit's morphodynamics was related to extreme river flow events, wave and wind conditions; afterwards the spit stabilized its shape and increased its area and volume. In the second case study the coast of Vila Nova de Gaia was broadly analysed, including the shoreface, foreshore and dunes, the characterization of major features and a short-period analysis of installed dynamics. Results obtained from field data, topographical surveys and numerical wave models were combined for an erosion risk assessment, using a methodology specifically developed for the study area.

Both monitoring programs achieved their proposed objectives and provided valuable information to the local authorities, as gathered and processed information constitutes a valuable database for coastal planning and for ICZM purposes. They demonstrate the potential of several approaches, supported by advanced technologies, for the study of complex coastal morphodynamic processes.
\end{abstract}

Keywords: monitoring techniques; Digital Elevation Models; morphodynamics; coastal erosion; risk assessment; Douro Estuary; Vila Nova de Gaia; Portugal.

\footnotetext{
@ Corresponding author: <anabio@ciimar.up.pt>

${ }^{I}$ CIMAR/CIIMAR - Centro Interdisciplinar de Investigação Marinha e Ambiental, Universidade do Porto, Rua dos Bragas, 289, 4050-123 Porto, Portugal

${ }^{2}$ Departamento de Geociências, Ambiente e Ordenamento do Território, Faculdade de Ciências da Universidade do Porto, Rua Campo Alegre 687, 4169 - 007 Porto, Portugal

${ }^{3}$ Department of Earth Sciences, University of Minho, Campus de Gualtar, 4710-057 Braga, Portugal

${ }^{4}$ Department of Civil Engineering, University of Minho, Campus de Gualtar, 4710-057 Braga, Portugal

${ }^{5}$ Centro de Geologia da Universidade do Porto, Rua Campo Alegre 687, 4169 - 007 Porto, Portugal

${ }^{6}$ Department of Mathematics, Universidade de Trás-os-Montes e Alto Douro, Apartado 1013, 5001-801 Vila Real, Portugal

${ }^{7}$ Observatório Astronómico, Faculdade de Ciências da Universidade do Porto, Monte da Virgem, 4430-146 Vila Nova de Gaia, Portugal
}

* Submission: 14 JAN 2014; Peer review: 6 FEB 2014; Revised: 26 MAR 2014; Accepted: 3 APR 2014; Available on-line: 11 APR 2014 


\section{Resumo}

\section{Métodos de monitorização e análise de risco de erosão costeira: dois casos de estudo portugueses}

Zonas costeiras são sistemas naturalmente dinâmicos e móveis, expostos a fatores naturais (fluxos de rios, ondas e tempestades) e intervenções humanas, que alteram continuamente a sua morfologia. Fenómenos de erosão relacionados com temporais e escassez de sedimentos são comuns. Eles ameaçam construções e infraestruturas, praias, ecossistemas e zonas húmidas, o que constitui um desafio para a segurança e defesa costeiras. Uma monitorização regular de áreas costeiras, com avaliação da sua morfodinâmica e identificação dos processos que influenciam o transporte de sedimentos, visando uma melhor compreensão das alterações e tendências evolutivas nos sistemas costeiros, torna-se portanto cada vez mais importante. Para tal necessita-se de uma abordagem multidisciplinar e investigadores especializados em processos costeiros e tecnologias de observação de ponta.

O presente trabalho descreve e avalia métodos de monitorização de última geração para uma quantificação eficiente de alterações em ambientes costeiros e apresenta dois estudos de caso Portugueses. Os métodos de observação incluem: levantamentos topográficos terrestres em modo cinemático baseados em videogrametria; levantamentos topográficos aéreos baseados em fotogrametria; batimetria sub-tidal e imagens de fundo obtidas com sonar a partir de um veículo autónomo de superfície; e observações de campo com análise de sedimentos e caracterização de praias. O primeiro caso de estudo referese à análise de padrões de erosão e acreção na restinga do estuário do Douro, tendo em conta efeitos causados pelo molhe, o caudal do rio, ondas e vento. Antes da construção de um molhe destacado, a morfodinâmica da restinga estava relacionada com eventos extremos de caudal, agitação marítima e vento. Após a construção, a forma da restinga estabilizou e observou-se um aumento da sua área e do seu volume. No segundo caso de estudo, a costa de Vila Nova de Gaia foi amplamente estudada, incluindo shoreface, foreshore e dunas, com a caracterização dos principais atributos e uma análise de curto-período da dinâmica instalada. Os resultados obtidos a partir de dados de campo, dos levantamentos topográficos e de modelos numéricos de ondas foram combinados numa análise de risco com métodos especificamente desenvolvidos para a área de estudo.

Ambos os programas de monitorização atingiram os seus objetivos e geraram informação relevante para as autoridades locais. A informação recolhida e processada constitui uma base de dados valiosa para o planeamento costeiro e a Gestão Integrada de Zonas Costeiras. Os estudos demonstram o potencial das diversas abordagens, apoiadas por tecnologias avançadas, para o estudo dos processos complexos de morfodinâmica costeira.

Palavras chave: técnicas de monitorização; Modelos Digitais de Elevação; morfodinâmica; erosão costeira; análise de risco; estuário do Douro; Vila Nova de Gaia; Portugal.

\section{Introduction}

Being land-ocean interfaces, and river-ocean interfaces at estuaries, coasts constitute transitional zones of high ecological, as well as economical importance. Exposed to different phenomena that continuously reshape their morphology, coasts are naturally dynamic and mobile systems. They constantly adapt in response to natural forcing factors (currents, waves, winds and storms), but also to human interventions, like sand mining, and construction of edifications and defence structures. Many coasts suffer from erosion processes, causing coastal retreat that threatens beaches, wetlands, marshes and coastal ecosystems, as well as buildings and infrastructures, hence stressing local economies. For instance, almost all coastal EU Member States have problems with coastal erosion, with more than $20 \%$ of the evaluated European coastline affected (Niesing, 2005). In an effort to mitigate erosion, soft (e.g. beach nourishment) and hard defences (e.g., groins or breakwaters) are built against sea impacts. Hard defence structures are however static and interfere with natural coastal dynamics and the accommodation space for adaptation, and their medium to long-term effects are frequently unexpected as there is often not enough quantified knowledge about the local coastal dynamics and the forcing factors and processes driving it.
Coastal erosion is complex and depends on the off and on-shore environment, including wave energy and direction, weather and climate, the materials that make up the coast and the supply or extraction of sediments, as well as the influence of manmade structures (Archetti \& Zanuttigh, 2010; Granja \& Pinho, 2012). Monitoring should consider these interactions and be as comprehensive as possible, including the submerged part of the shore to obtain important information on slope, bathymetry and the bottom features and materials (Holland et al., 2009).

For a responsible and sustainable coastal management, it is necessary to understand the coastal system, its physical processes (e.g., sediment transport patterns, sediment sources and sinks), forcing factors (e.g., wave action, storm surges, currents) and their interrelations and effects. Coastal morphology and its dynamics have to be followed and quantified along time, and erosion risks have to be evaluated considering present and potential future (e.g., climate change) scenarios (Nicholls et al., 2007; Dodet et al., 2010; Pereira \& Coelho, 2013).

Several methods have been proposed for coastal morphodynamic monitoring. Coasts can be analysed in terms of shoreline dynamics only (Boak \& Turner, 2005) or in terms of beach morphology changes. 
Surveys using conventional techniques, such as classic surveying equipments (Holland et al., 2009; Cowart et al., 2010; Souza \& Luna, 2010; Muehe, 2011), are both costly and labour-intensive, and generally lack the spatial and temporal resolution needed to identify and quantify short-term changes as well as long-term trends (Short \& Trembanis, 2004). Alternatives using fixed video imagery (Davidson et al., 2007; Archetti \& Zanuttigh, 2010) provide lower-cost continuous data, i.e. an optimal temporal resolution, but are generally limited to few beach stretches. Remotely sensed data have also been successfully used for coastal monitoring. Satellite radar, particularly Synthetic Aperture Radar (SAR), have been used to extract shoreline information (Niedermeier et al., 2000) and aerial digital photography to obtain 3D information through photogrammetric analysis (Fletcher et al., 2003; Cowart et al., 2010). Laser surveys may deliver similar (or slightly better, $10-15 \mathrm{~cm}$ ) accuracy in the vertical component and may constitute an alternative to aerial digital photography and photogrammetry; but they are still extremely expensive. The generalisation of GPS (Global Positioning System) methods, particularly those using RTKGPS (Real-Time Kinematic GPS), has facilitated analysis of spatial variability allowing precise threedimensional survey data to be collected both rapidly and at high spatial resolution (Rocha et al., 2009; Barnard \& Warrick, 2010). A novel approach to topographic surveys is videogrammetric mobile mapping, where $3 \mathrm{D}$ coordinates are extracted from stereo video images (Madeira, 2007; Zhu \& Brilakis, 2009; Brilakis et al., 2011).

The main objectives of this paper are: (1) to present an overview of state-of-the-art coastal survey techniques, including novel methods for coastal topography definition, such as terrestrial videogrammetric mobile mapping and aerial digital photogrammetry, and (2) to show their potential in morphodynamic monitoring and erosion risk assessment and, hence, integrated coastal management. Two case studies are used to illustrate the applicability of the methods. The first refers to the Douro Estuary sand spit, where the effects of a detached breakwater on spit morphodynamics were analysed based on more than a decade of regular surveys and considering river flow, wave and wind patterns. The second refers to a comprehensive monitoring program developed to assess erosion risk for the coast of Vila Nova de Gaia.

\section{Coastal monitoring methods}

In this section, the several survey techniques used in the case studies are presented. The first case study, concerning the evolution of the Douro spit, used Digital Elevation Models (DTM) derived from terrestrial mobile mapping surveys. The second consisted of a multi-disciplinary monitoring approach, aiming at a comprehensive evaluation of morphodynamic trends and erosion risks in the coastal system. Analyses were based on results from the simultaneous and integrated use of terrestrial mobile mapping surveys, as well as airborne digital photography surveys, bathymetric surveys, in-situ field observations, beach profiling and sediment sampling.

\subsection{Terrestrial mobile mapping surveys}

Traditional land surveying methods are time consuming, and therefore also expensive. A much more efficient alternative is the use of a Mobile Mapping System (MMS), using a direct georeferencing system and video cameras, which is easily and quickly put into operation under almost any weather conditions. The observing methodologies applied in our case studies, evolved with time. In the sand spit study, surveys started with an on-foot GPS equipment (used until 2002), followed by a two antenna system installed on a moto-quad (from 2003 to 2009) (Baptista et al., 2008) and, more recently (since 2009), by a videogrammetric (Fig. 1), which can be used with different direct georeferencing systems, developed at the University of Porto (Madeira, 2007; Madeira et al., 2010). In the second case study, only the two-antenna system was applied.

Automated spatial data collection using terrestrial videogrammetric MMS in coastal zones is still at an early stage of development (Zhu \& Brilakis, 2009; Brilakis et al., 2011). Software developed at the University of Porto (UP), Portugal, was applied to automatically extract 3D coordinates (Madeira et al., 2010). A process was developed that relies on an automatic selection and coordination of ground points in each pair of photogrammetric images obtained by the system's video cameras. The DEM was computed creating a TIN (triangulated irregular network) and converting it to a regular grid (with $1 \mathrm{~m}$ spacing) by linear interpolation.

With an adequate direct georeferencing system, data acquired with the MMS implemented at UP allow 3D topographic mapping with accuracies similar to those of RTK-GPS based methods (Dail et al., 2000). The method to obtain the DEM from the image-derived coordinates does not depend on the relative changes between the GPS antenna and the ground but only on the calibration of the cameras (which can be done very precisely, at the sub-pixel level; Madeira et al. 2009) and the determination of the relative position of the GPS antenna and the video cameras.

The relative position of the cameras and the GPS/INS direct georeferencing system can also be accurately established before mounting the system, and will remain constant for each installation. DTM height accuracies, tested with control points, were at the fewcentimetre level $(\mathrm{RMS}=0.06 \mathrm{~m})$. 

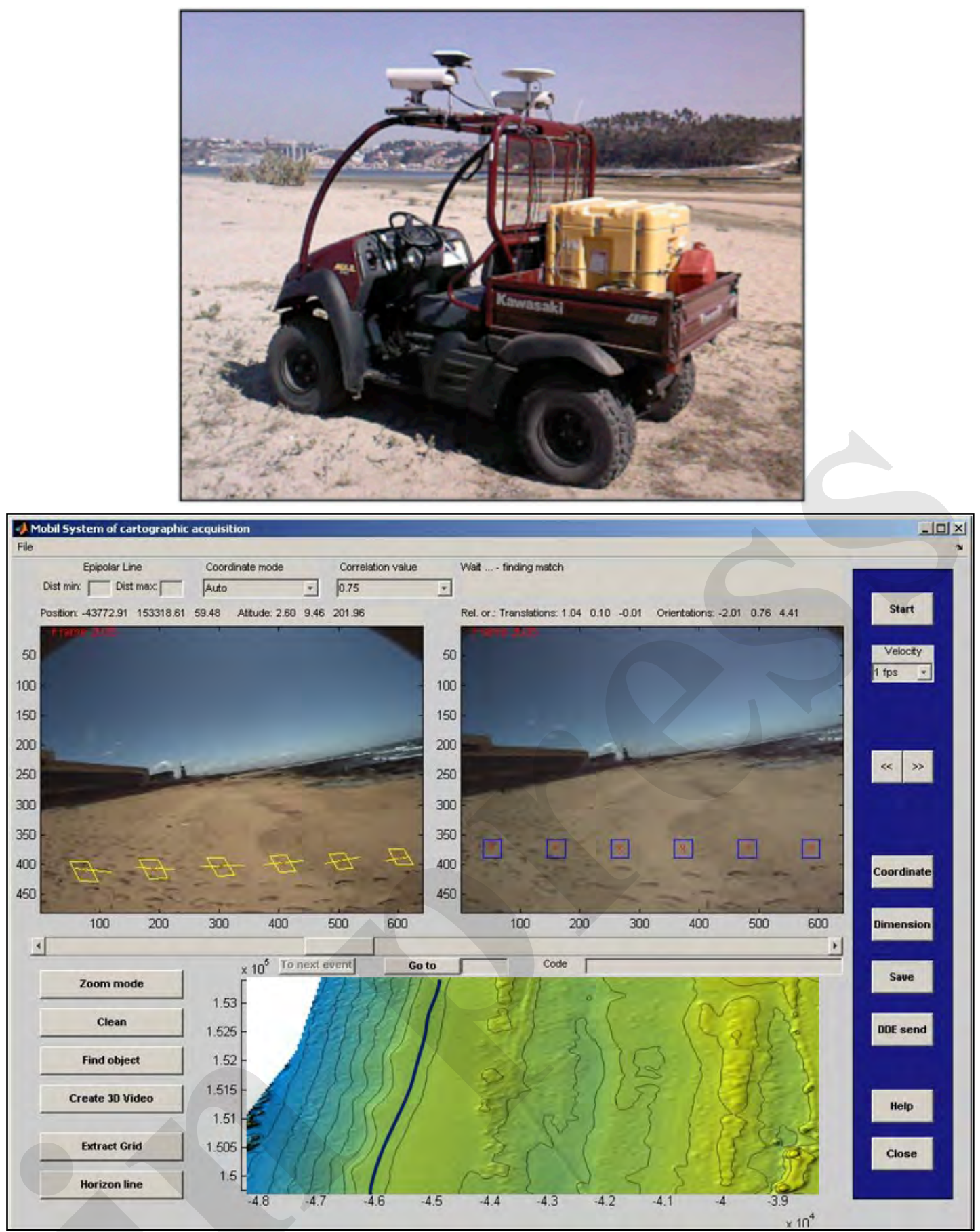

Figure 1 - Terrestrial mobile mapping survey. A: Four-wheel vehicle with two kinematic antennas and videogrammetric equipment; B: Screenshot of the software used to extract topographic coordinates and terrain features.

Figura 1 - Levantamento terrestre em modo cinemático. A: Carro equipado com duas antenas cinemáticas e equipamento de videogrametria; B: Imagem de ecrã do programa usado para extrair as coordenadas topográficas e atributos de terreno.

A further advantage is the simultaneous (video) recording of ground features, such as dune vegetation or storm scars, with a resolution of a few centimetres, superior to that achieved by traditional aerial photography. These records can be of upmost relevance for ecological and geomorphological interpretation of the environment, and can be compiled in GIS databases for further analysis.
Measurements with the MMS were collected continuously, in kinematic mode, using GPS post-processing relative positioning. Positioning and orientation of the cameras was initially done using a GPS-only dual frequency multi-antenna setting to derive roll and later a GPS/INS georeferencing system based on a dual frequency GNSS receiver and a navigation-grade IMU (Inertial Measurement Unit), which allows determina- 
tion of the vehicle orientation in all three angular directions (roll, pitch and heading). Here, we present results obtained using the latter setting.

\subsection{Airborne photogrammetry}

Aerial photos were taken using a digital camera (ZI Imaging DMC) installed in an airplane flying at about $1030 \mathrm{~m}$ height (Fig. 2). This resulted in high-resolution images with $10 \mathrm{~cm}$ ground sampling distance (GSD). Two strips of images were collected, with a longitudinal overlap of $60 \%$ and a lateral overlap of $30 \%$. Images were collected during spring low tides to maximize the observable emerged area.

Images were directly georeferenced by a GPS/INS system. The GPS post-processing relative positioning mode was used, and the information was processed to obtain the centre of camera projection and the attitudinal angles for each image. A boresight alignment was done with ground control points in order to correct slight systematic effects in the attitude angles of about 0.02 degrees (Gonçalves et al., 2011). Calibration was done in built up areas, which contain features that can be used as accurate ground control points.

DEMs were computed from the pairs of stereoscopic aerial images after extracting correlated points through stereomatching, using the BLUH software (Jacobsen, 2000; Rieke-Zapp \& Nearing, 2005). Notice that stereomatching is difficult with images of sandy, low-contrast beaches due to light over-exposure. Whenever possible, surveys were therefore conducted under low-sun conditions, when some shadow patterns appear in the sand, which facilitate image correlation. The digital photographs were furthermore orthorectified and combined
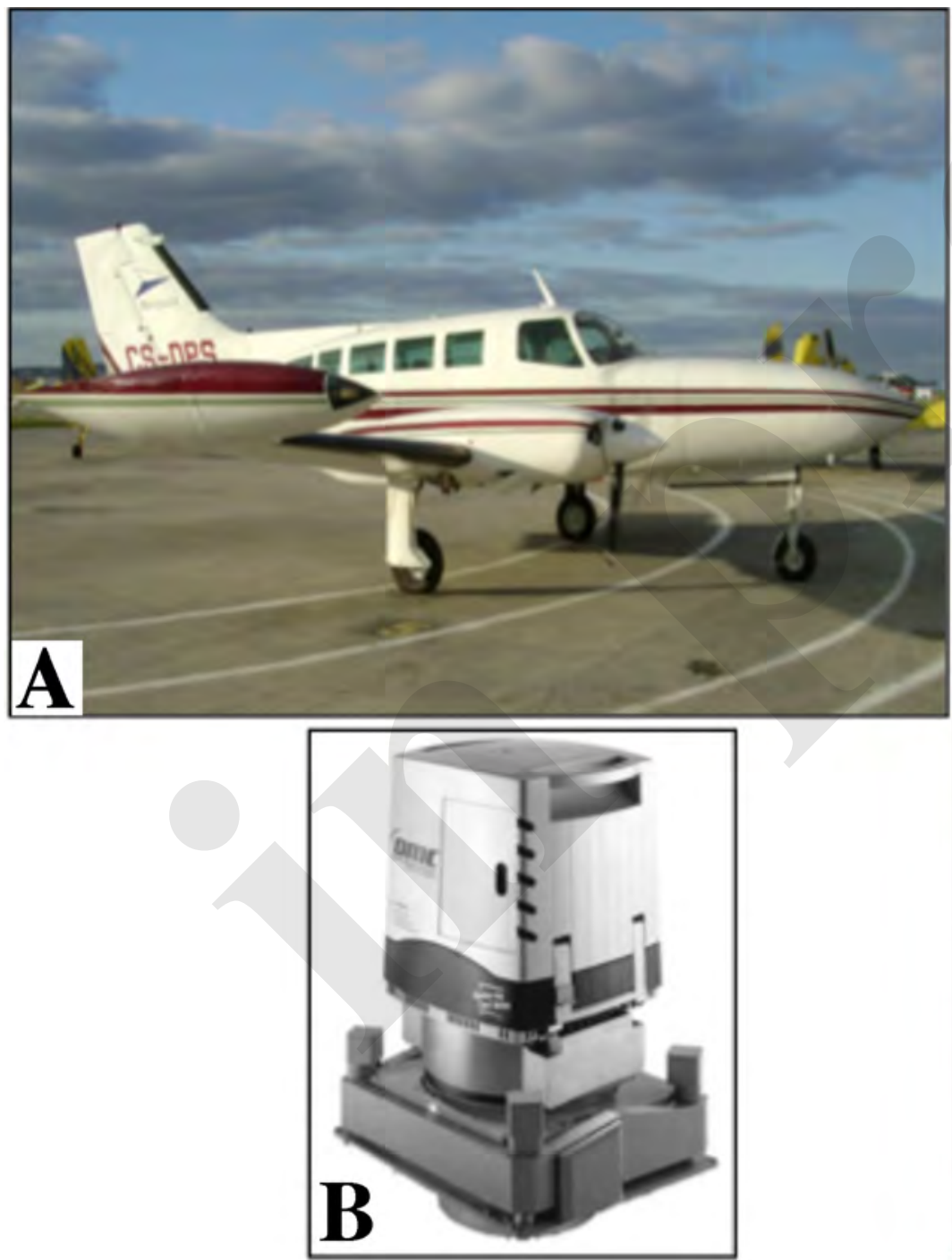

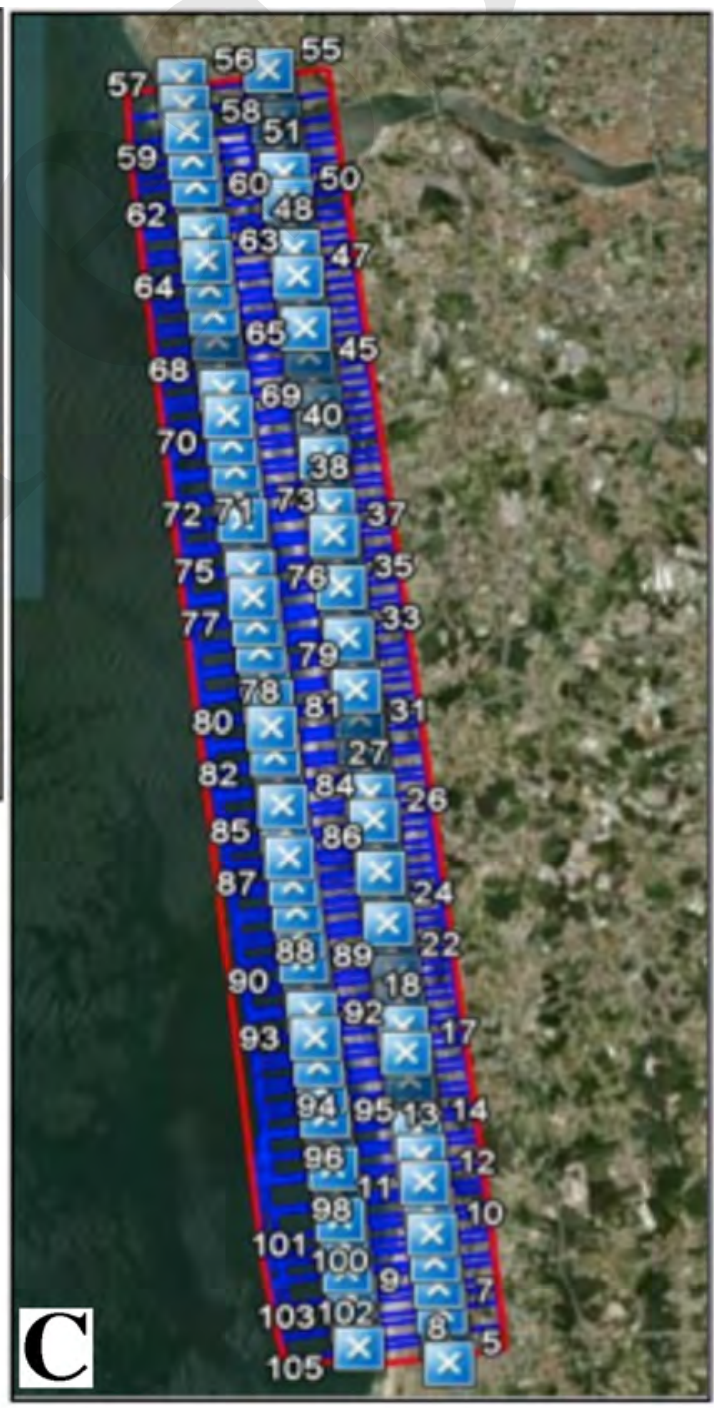

Figure 2 - Airborne photography survey. A: Survey airplane; B: digital ZI-DMC camera (sensor with 7680×13824 pixels); C: Flight plan with two rows of overlapping photos (here: $\sim 100$ photos covering $\sim 14 \mathrm{~km}$ ).

Figura 2 - Levantamento por fotografia aérea. A: Avião utilizado; B: câmara digital ZI DMC (sensor com $7680 \times 13824$ pixéis); C: plano de voo com as duas fiadas de fotografias sobrepostas (neste caso: $\sim 100$ fotos que cobrem $\sim 14 \mathrm{~km}$ ). 
into mosaics with $0.1 \mathrm{~m}$ resolution, for visual analysis of ground occupation and patterns. DTM height accuracies, tested with control points, were at the few decimetre level $(\mathrm{RMS}=0.18 \mathrm{~m})$.

\subsection{Bathymetric surveys}

An Autonomous Surface Vehicle (ASV), a remotely computer controlled, $4.2 \mathrm{~m}$ long catamaran (Fig. 3), was used for bathymetric surveys (Ferreira et al., 2009). Vehicle navigation and positioning was done with a PolaRx RTK GPS, with a horizontal accuracy of $2 \mathrm{~cm}$ and a vertical accuracy of $4 \mathrm{~cm}$. The platform was furthermore equipped with a Tritech digital single beam side-scan altimeter sonar; a $500 \mathrm{KHz}$ echo-sounder with 60 conical beam width and $1 \mathrm{~cm}$ of range resolution, measuring bathymetry and capturing acoustic images of the ocean bottom. The ASV was electrically propelled and the sonar sensor heads mounted at the aft of the boat without interference from the hull motion and propeller induced noise.

The system allowed for continuous recording of all data, including navigation data and the observation time. The derived horizontal coordinates were referred to the ETRS89 datum and depths referred to CD (Chart Datum). Bathymetry data were used for the implementation of a wave propagation model. Reflectance and shadows of the sonar images from the side-scan were also analysed to identify rocky outcrops and sandy patches.

The accuracy of the bathymetric surveys was not evaluated by the authors. In controlled environments (harbours), the catamaran showed accuracies at the few centimetre level. At the coast and under ideal conditions, depth could be measured with an accuracy of about $15 \mathrm{~cm}$. However, due to the variability of observation conditions in the ocean, in practise, all existing remote techniques (including echo- sounder, laser, etc.) usually deliver a worse final accuracy, with precisions not better than 20 to $30 \mathrm{~cm}$. Notice that the catamaran-based system is not introducing additional errors or limitations, when compared to traditional bathymetric hydrographical surveys, and has advantages concerning the depth of the zone that it can survey. Compared to manned surveys, autonomous computer controlled robotic surveys allow higher precision in course control. They are furthermore cheaper and safer to operate under rough conditions.

\subsection{Field observations and sedimentary analyses}

For erosion risk assessment coasts need to be observed and characterized, giving particular attention to geo and bio- indicators of coastal short term change and to the segments most sensitive to erosion. In our case study, location, type and state of the beach-dune system pro-

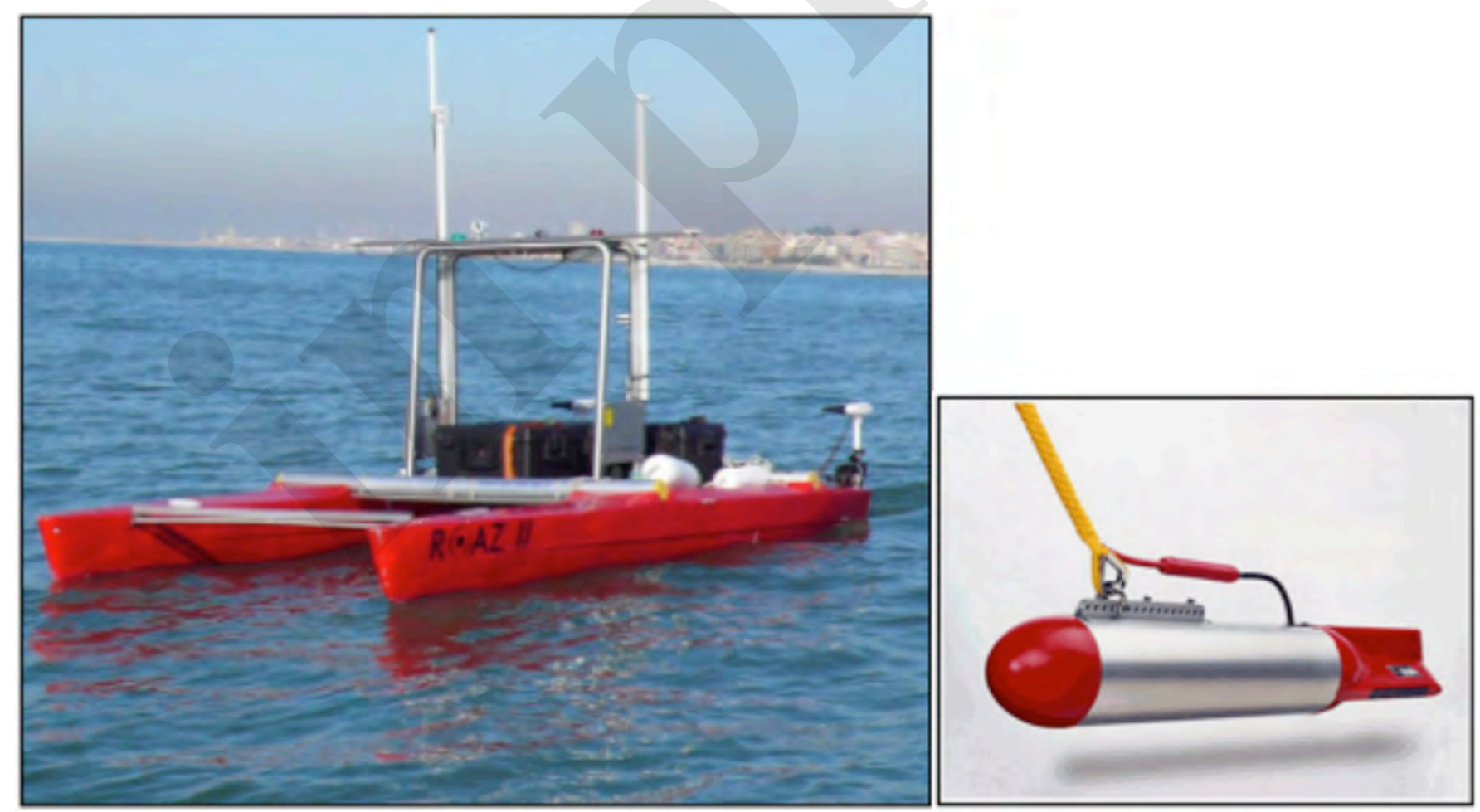

Figure 3 - Bathymetric and seabed survey. A: Autonomous catamaran, platform with GPS RTK and altimeter; B: Side-scan sonar.

Figura 3 - Levantamento batimétrico e do fundo. A: Catamarã autónomo, plataforma com GPS RTK e altímetro; B: sonar de varrimento lateral. 
file, grain size of sediments, regularity of the dune ridge, dune vegetation, as well as micro-forms like blowouts, cliffs, washovers, ridge and runnels, and cusps were recorded.

Sediment size data were obtained through sieving and processed using the SEDMAC software (Henriques, 2004) to obtain commonly used size parameters for particle populations. Data obtained included relative and cumulative frequencies in 1/2Ø (phi) intervals. Mean, standard deviation, skewness and kurtosis were determined, using the method of moments. The distribution of size fractions according to the modified Wentworth scale was also determined. Sample distribution by dimensional $1 / 2 \varnothing$ class was done in correspondence to the metric scale. Sediment size and statistics were processed and integrated in a GIS, using the sediment samples' spatial reference.

\section{Case Studies}

\subsection{Study area}

The case studies refer to the Douro river barrier sand spit and the coast line south of it (Fig. 4). The Douro River has a funnel-shaped estuary that lies embedded in a steep valley, extending $21.6 \mathrm{~km}$ from the CrestumaLever dam, which sets an artificial limit to the estuary, to the river mouth (Portela, 2002). The river has a torrential regime, regulated by 15 dams (seven in the Spanish and eight in the Portuguese territory). Water flows to the estuary depend on water levels and on hydropower generation needs. Periods of null-discharge flows are frequent, mostly during summer, as well as floods (with river flood discharges reaching more than $13000 \mathrm{~m}^{3} \mathrm{~s}^{-1}$ ) in winter or spring, when the dams' limited water storage capacity is not enough to prevent them.

The estuary inlet is protected by a sand spit (Fig. 4C). This spit is rooted on the left bank of the Douro river estuary and points north due to the S-N drift caused by wave diffraction around the ebb-tidal delta and some outcrops, and the breakwater to the North of the outlet. The spit is presently about $300 \mathrm{~m}$ wide (east-west) and $700 \mathrm{~m}$ long (north-south). Its Eastern flank is stabilized by plants like Elymus farctus and Ammophilla arenaria and connects with the São Paio Bay, a mostly submerged (1-2 m below $\mathrm{CD}$ ), hydrodynamically calm wetland of ecological importance. Composed of fine to medium-coarse sand, the spit is influenced by subaerialfluvio-marine conditions, including; sedimentary transport by the river, swell and tide effects, as well as by winds (Silva et al., 2005; Consulmar, 1996).

There are numerous records of flood events that caused rupture of the spit and of periods when accretion took place at the spit tip, causing its progression towards the North and even obstruction of the navigation channel. Between 2004 and 2008 the Northern breakwater was extended and a new detached breakwater was built at the spit tip in order to: stabilize the estuary margins, especially those of the sand spit and the estuary outlet; improve navigability and navigation safety under any tide condition; reduce propagation of storm waves into the estuary; preserve environmental values (most of the sandy spit and the adjacent São Paio Bay constitute a Nature Reserve); and reduce the dredging needed to maintain the navigation channel.

South of the river mouth lies the $15 \mathrm{~km}$ long coastal stretch of Vila Nova de Gaia (Fig. 4C). Many parts of that coast have shown progressive erosion in recent

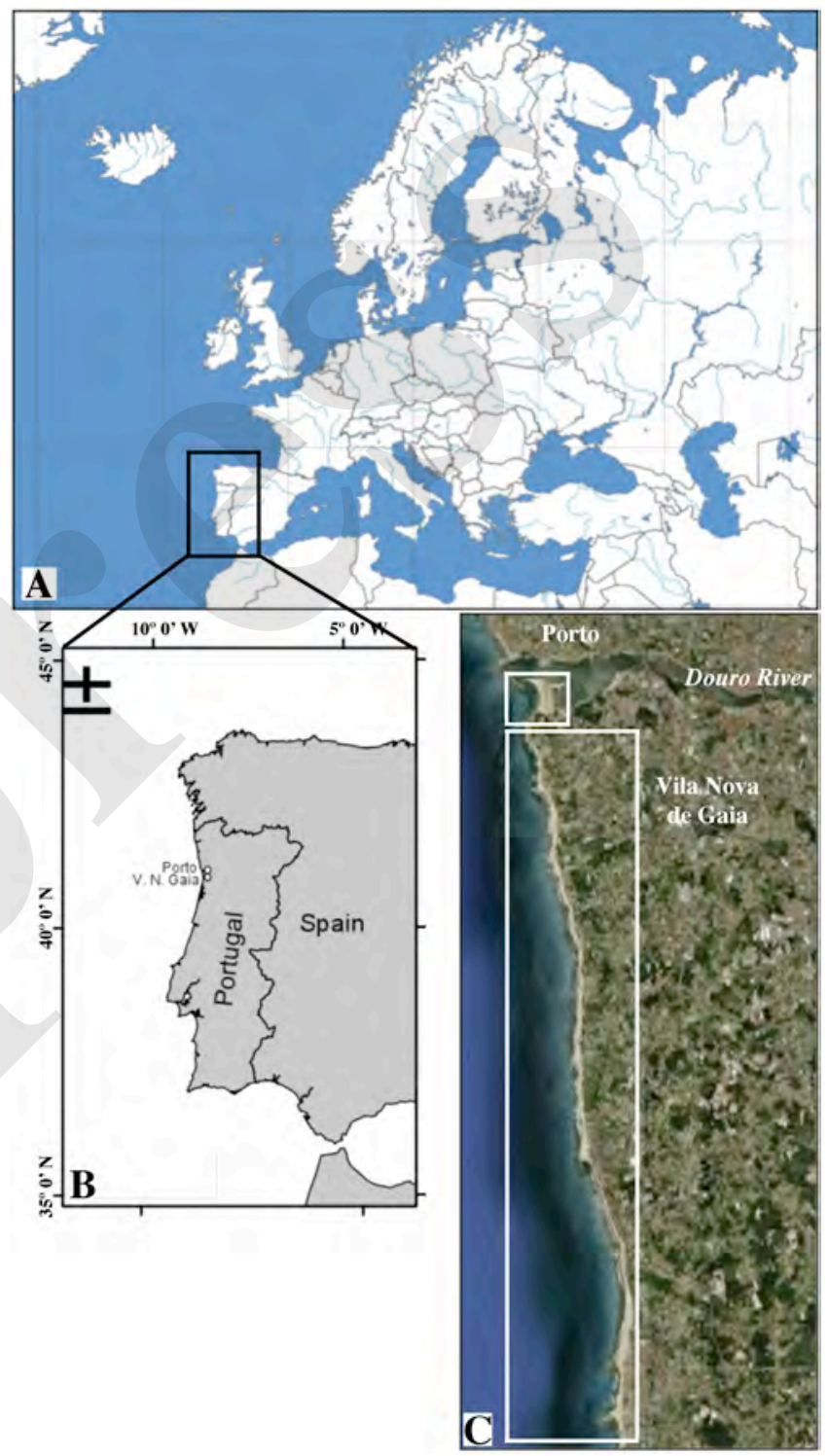

Figure 4 - Case study areas. A: Portugal (box) in SW-Europe; B: Location of Porto and Vila Nova de Gaia on the NWAtlantic Portuguese coast; C: GoogleEarth image of the two study areas (boxes), the Douro spit in the North and the coast of Vila Nova de Gaia municipality to the South of it.

Figura 4 - Áreas de estudo. A: Portugal (retângulo)no SO da Europa; B:Localização do Porto e de Vila Nova de Gaia na costa NO-Atlântica de Portugal; $C$ : imagem GoogleEarth das duas áreas de estudo (retângulos), a restinga do Douro no norte e a costa do município de Vila Nova de Gaia a sul. 
decades (Granja \& Carvalho, 2000; Soares de Carvalho et al., 2006), with coastal retreat reaching, in some cases, six meters per year, challenging coastal security and protection. Several causes for erosion have been pointed out: increasing lack of sediment supply from rivers (due to dam construction since the 50's, dredging and extraction of aggregates); sediment starvation in the inner continental shelf; influence of coastal defence structures; and an increase in storm surge frequency and intensity (though this is controversial).

At these latitudes $\left(40^{\circ}-42^{\circ} \mathrm{N}\right)$, the North-Western Portuguese coast is highly energetic (Cruz, 2008), with offshore mean significant wave heights of 2-3 m, and mean wave periods of $8-12 \mathrm{~s}$. In winter, storms generated in the North Atlantic are frequent and can persist for up to five days, with significant wave heights reaching $8 \mathrm{~m}$ (Costa et al., 2001). The tides are semidiurnal, with heights ranging from $2 \mathrm{~m}$ to $4 \mathrm{~m}$ during neap and spring tides, respectively. Waves are usually coming from the W-NW, causing a dominant drift current from North to South (S-N drift is occasionally observed during W-SW storm periods). This current is in some areas inverted due to the presence of obstacles that promote wave diffraction, as happens at the Douro spit. At Vila Nova de Gaia, the main drift direction is N-S, causing accretion northwards of obstacles (drainage pipes, breakwaters) and erosion to the South (Granja et al., 2011).

\subsection{Douro estuary sand spit study}

\subsubsection{Monitoring and data analysis}

In June 2001 a monitoring program was set up to monitor the Douro Estuary sand spit, measuring its position, shape and volume, and assess its evolution. These data were later analysed with the objective to identify relationships between sand spit dynamics and river flow regimes, ocean wave and wind patterns, and to evaluate the impact of the breakwaters on spit morphology and on its vulnerability to river flow, wave and wind conditions.

Using GPS in relative kinematic mode (see Section 2.1), quarterly terrestrial mobile mapping measurements were taken along the instanta-neous water limit (i.e., of the sand spit edge) and on a grid of profiles, allowing determination of the spit's contour and topography, and subsequent production of DEM representing its 3D surface (Fig. 5). DEM were used to analyse spit evolution in time, distinguishing between the periods before and after breakwater construction.

Changes in sand spit shape, area, topography and volume were related to extreme river flows discharges, ocean wave and wind conditions, considering: (i) maximum daily mean river flow discharges; (ii) the number of days with discharge flows higher than $800 \mathrm{~m}^{3} \mathrm{~s}^{-1}$; (iii) maximum wave power events (with wave power in $\mathrm{kW} \mathrm{m}^{-1}$ estimated by $\approx 0.5 \mathrm{~kW} \mathrm{~m}^{3} \mathrm{~s}^{-1} \times$ wave height ${ }^{2} \times$ period); (iv) number of 3-hour periods with wave power values above $200 \mathrm{~kW} \mathrm{~m}^{-1}$; (v) maximum wind power (which was estimated as the cube of the maximum wind speed; Rasmussen et al., 2011); and (vi) the number of half-hour periods with wind power values above $10000\left(\mathrm{~m} \mathrm{~s}^{-1}\right)^{3}$.

Daily average discharge records at the Crestuma-Lever dam (supplied by INAG - Portuguese Water Authority, under permission of the EDP - Portuguese Electrical Company) were taken to represent total freshwater flow

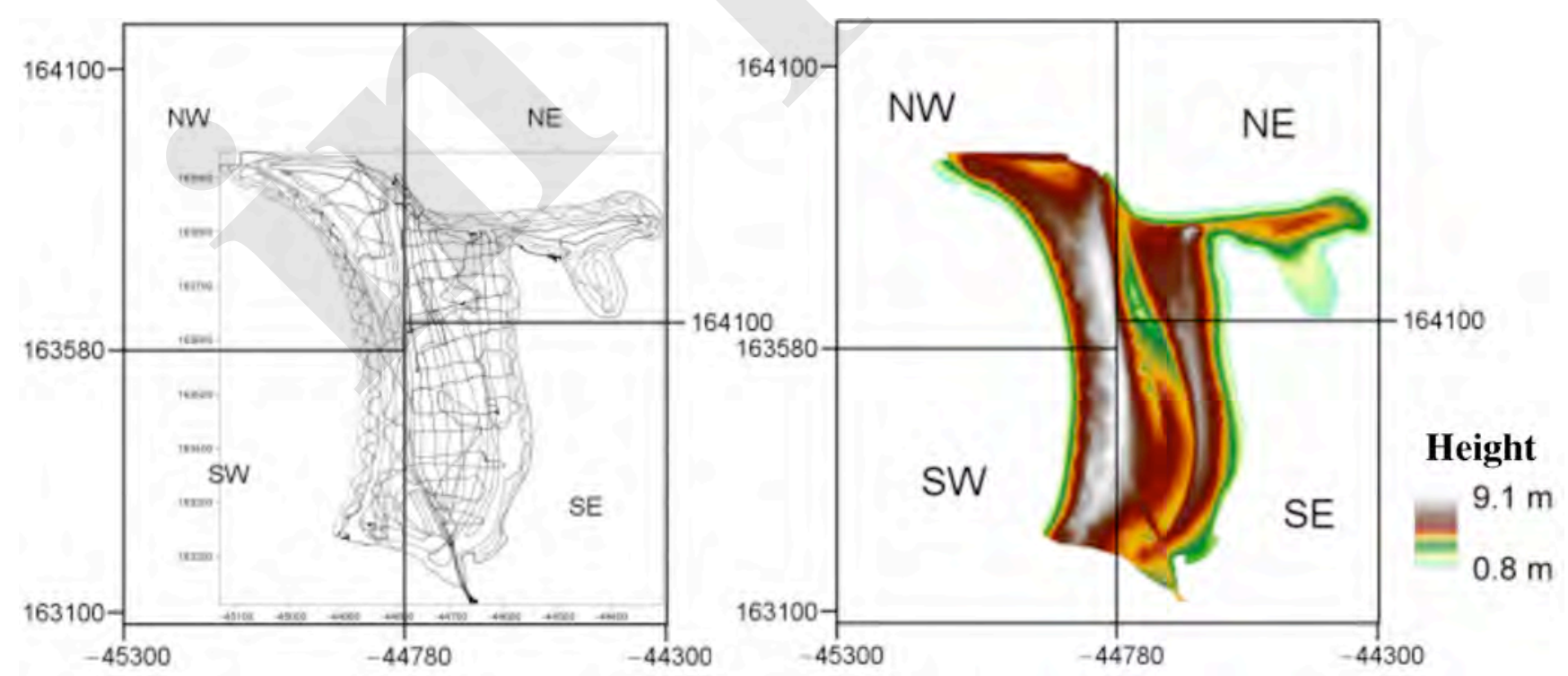

Figure 5 - Sand spit survey. A: Distribution of samples collected during in June 2009 (each dot is an observation) and delimitation of the four spit sectors analysed (coordinates are in Datum 73, Hayford-Gauss, IPCC); B: resulting DTM.

Figura 5 - Levantamento da restinga. A: Distribuição das amostras recolhidas em Junho de 2009 (cada ponto é uma observação) e a divisão nos quatro sectores analisados (com coordenadas em Datum 73, Hayford-Gauss, IPCC); B: MDT resultante. 
into the estuary. Wave data were obtained at 3-hour intervals, from a datawell directional wave buoy located about $32 \mathrm{~km}$ NW of the sand spit (41019'N, 8059'W), at $83 \mathrm{~m}$ water depth (supplied by IH - Portuguese Hydrographical Institute). Wind velocities were obtained from NCEP FNL Operational Model Global Tropospheric Analyses (National Center for Atmospheric Research, http://rda.ucar.edu/datasets/ds083.2/), at $41^{\circ} \mathrm{N}$ and $9^{\circ} \mathrm{W}$, considering the level of $1000 \mathrm{mbar}$.

To distinguish dynamics of different areas of the sand spit, the spit was divided into four sectors (Fig. 5): the seaward spit base (SW sector), the seaward tip (NW), the river facing spit base (SE) connected to the São Paio Bay wetland, and the river facing spit tip section (NE). For each sector and survey, sand spit area and volumes above different heights were determined. Changes between surveys were analysed, discriminating between the period before (Dec. 2001 to Jan. 2005) and after breakwater construction (June 2007, when most of the sand-spit breakwater structure was in place, to April 2010).

Correlations between these parameters and sand spit area and volume dynamics were assessed using Spearman correlation tests, as most pairs of data failed the Shapiro-Wilk normality test. All statistical analyses were carried out using $\mathrm{R}$ software (R Dev. Core Team, 2009).

\subsubsection{Results and discussion}

Considering sand spit shape and volume obtained from seasonal surveys between 2001 and 2009 (Bastos et al., 2012), three periods could be distinguished. The first, between 2001 and the end of 2003, was very dynamic, with marked changes of the sand spit tip shape and thickening and thinning of its body (Fig. 6; see Bastos et al., 2012 for more detail). The spit stayed stable during the second period, 2004 to early 2005, which coincided with a severe drought in continental Portugal with relatively low river flows. Decreasing volumes in the seaward sections and slightly increasing volumes in the NE spit tip sector were observed (Fig. 7). The third period was related to the construction of the breakwater attached to the sand spit, which started in March 2005.

During breakwater construction the spit tip developed an inland arm (along an older breakwater, which runs in E-W direction along the top of this arm), with a branch (Fig. 6). This inland arm was eroded by the time of the December 2006 survey, after a flood that occurred in the previous November, and was breached before the April 2010 survey after extreme river flows in the previous winter. Sand spit areas and volumes oscillated during breakwater construction, stabilizing from 2008 onwards for the eastern spit tip and displaying an increasing trend for the western sectors (Fig. 7).

Analyses revealed that the observed erosion and accretion patterns were related to extreme river flow, wave and wind conditions, with effects depending on spit section and height, and therefore exposure, and with distinctly different patterns for the periods before and after breakwater construction. Before breakwater construction, extreme river flow was significantly ( $p<$ $0.05)$ correlated with spit erosion. The number of days with extreme wave power was correlated with an increase in area and in the volume observed at lower heights (up to $4 \mathrm{~m} \mathrm{CD}$ ) of the NW sector. High wind power was related to losses in volume and to erosion in the SW sector, and to accretion in the NE. After breakwater construction river flow, wave and wind effects became overall less significant (see Bastos et al., 2012 for more detail). The breakwater seems hence to protect most of the spit against rough conditions, leading to a relative stabilization of the spit's shape and topography. The T-shape established after breakwater construction (due to the creation of a tombolo towards the detached breakwater and an inland arm), with little extension to the North, does not obstruct the navigation channel, and favours the navigability between the sea and the small estuarine harbours. There is, however, increasing silting up of the wetland area SE of the spit, due to changes in circulation patterns caused by the new spit shape, threatening the local Nature Reserve. In recent years, the São Paio Bay, has progressively filled up with sediment and is losing its wetland characteristics (pers. observation).

Furthermore, the strengthening of the spit bears risks for the riparian communities. In recent years, the spit has further stabilized and increased its area and volume (Fig. 6). In the period after the breakwater was built, the spit's area increased $\sim 56000 \mathrm{~m}^{2}$ (i.e. $\sim 23 \%$ ) and its volume $\sim 340000 \mathrm{~m}^{3}(\sim 33 \%)$. Its $\mathrm{W}$-face has moved 30-45 m westward, while the lower E-face remained stable. Prior to the sand spit breakwater construction, the sand spit used to rupture under severe floods, allowing discharge of the river flow through a wider cross section. A strengthened spit constitutes a more stable barrier and may cause floods with higher water levels within the estuary for a given flood discharge.

The monitoring of the Douro barrier sand spit is an ongoing project, integrated in a larger monitoring framework promoted by the APDL, which includes morphodynamical surveys in the Douro estuary, as well as monitoring of navigation conditions, damages and protections of harbours and other manmade structures. 

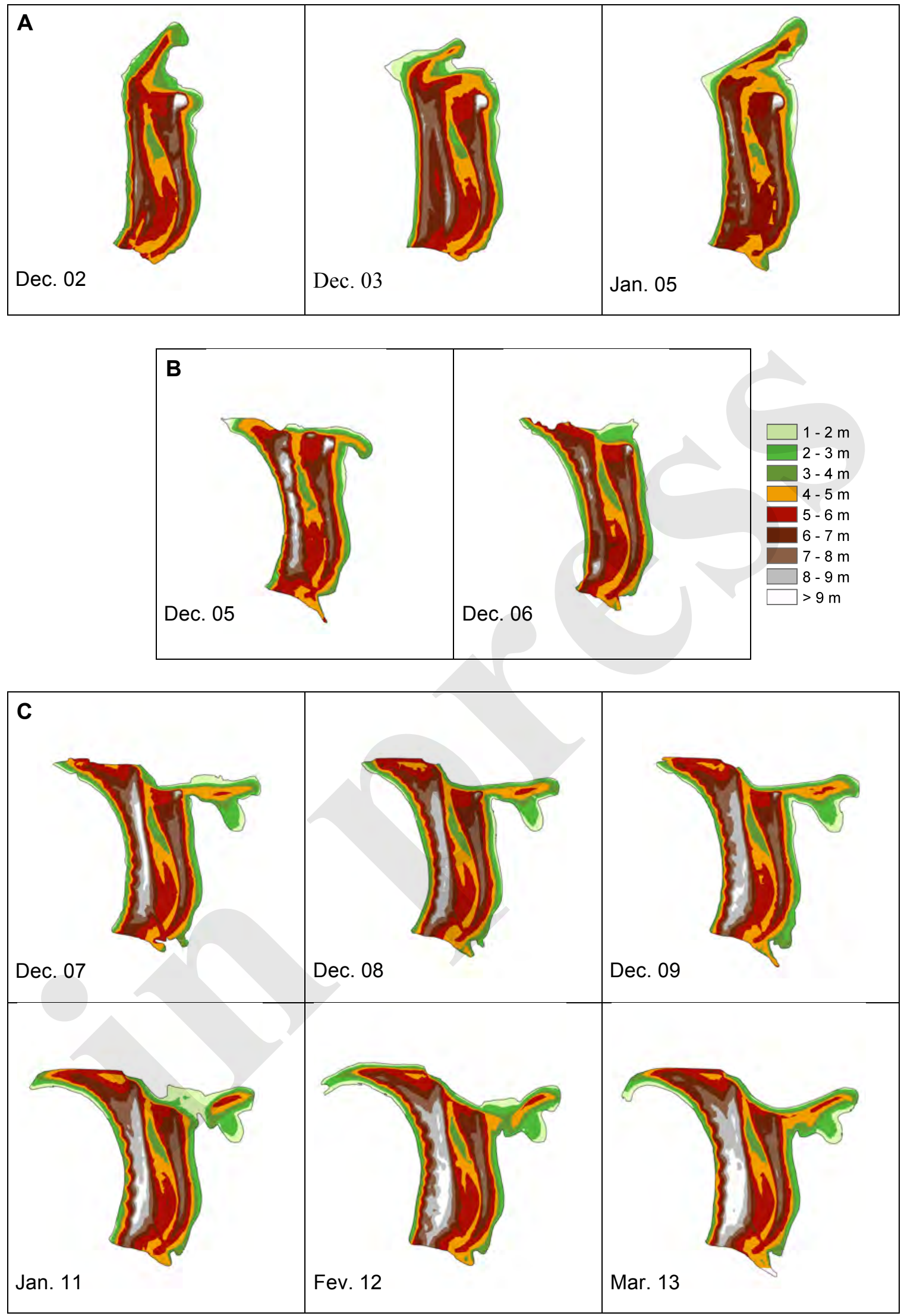

Figure 6 - DTM obtained from surveys carried out before (A), during (B) and after (C) the construction of the breakwater (a selection of yearly winter surveys is presented; more data can be found in Bastos et al., 2012).

Figura 6 - MDT obtidos em levantamentos antes $(A)$, durante $(B)$ e após $(C)$ a construção do molhe (apresenta-se uma seleção de levantamentos anuais de inverno; dados adicionais encontram-se em Bastos et al., 2012). 

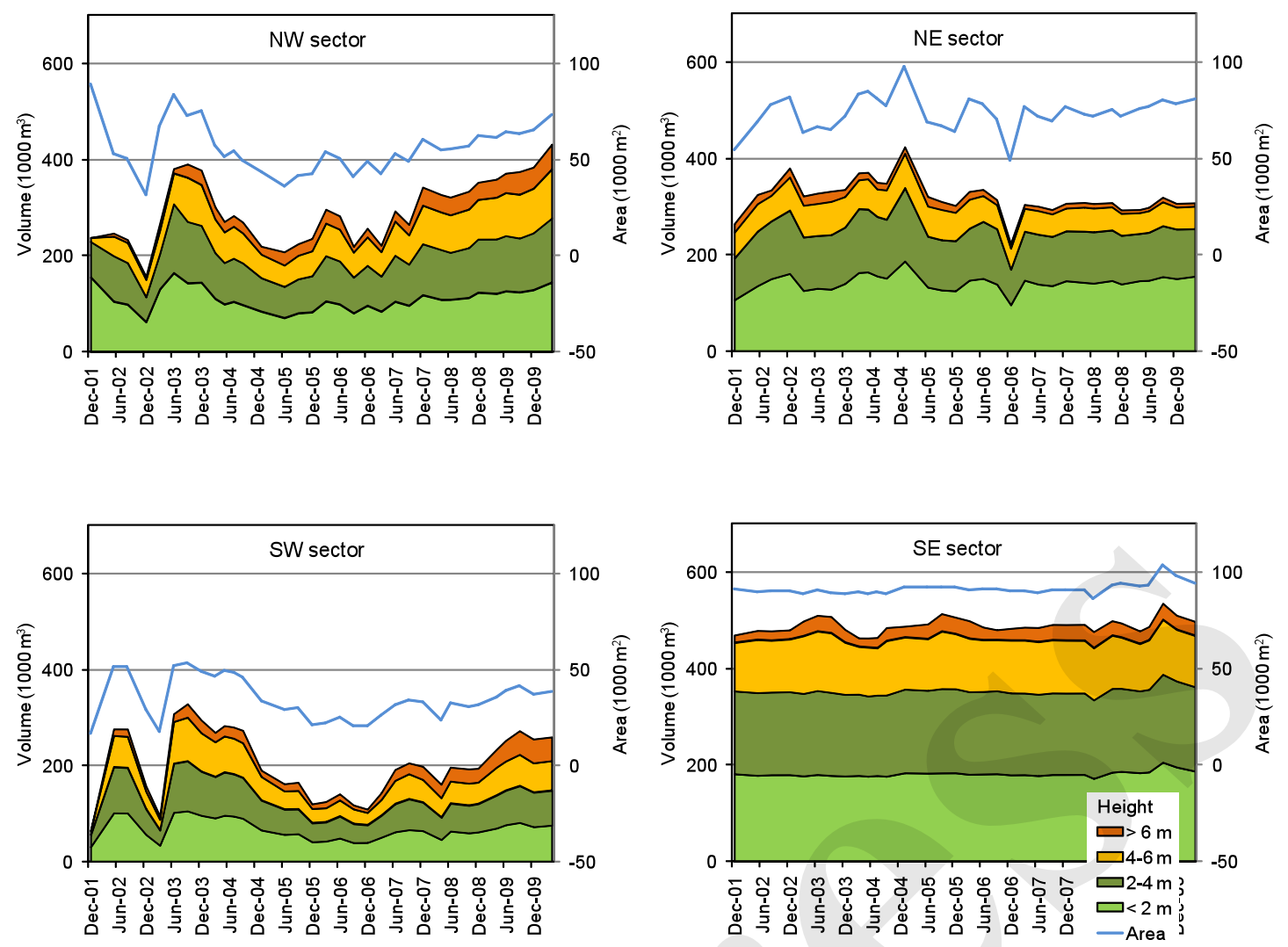

Figure. 7 - Variation in sand spit volume and area for the four sand spit sectors considered. The stacked area plots show volumes for different height layers and the line represents the total area of each sector.

Figura 7 - Variação do volume e da área da restinga para os quatro sectores considerados. As áreas empilhadas representam os volumes para camadas de diferentes altitudes e a linha a área total de cada sector.

\subsection{Vila Nova de Gaia erosion risk study}

\subsubsection{Monitoring and risk analysis}

In 2007, a multi-disciplinary monitoring program was set up to follow and quantify short-term changes of the densely occupied and locally erosion-prone Vila Nova de Gaia coast. The objective was to evaluate morphodynamic trends of the coastal system, including the shoreface, the foreshore and the dunes. Four campaigns took place, after fair weather conditions in the autumns of 2008 and 2009, and just after storm winter conditions in the springs of 2009 and 2010. An innovative set of monitoring methodologies was applied, including: mobile mapping surveys, airborne digital photography surveys for photogrammetric topography, bathymetric surveys and in-situ field observations, beach profiling and sediment sampling (see Section 2).

Bathymetric surveys were done along (E-W) profiles, more or less perpendicular to the coastline and up to 8 $\mathrm{m} \mathrm{CD}$ depth (i.e., $10 \mathrm{~m} \mathrm{MSL}$ ), during high tide, to allow driving the ASV as close as possible to the foreshore. Depending on the bottom slope, the profile lengths varied from $300 \mathrm{~m}$ to $2000 \mathrm{~m}$. Profiles were collected at $1 \mathrm{~km}$ intervals. A denser observation scheme would be recommended but was not feasible due to budget limitations. The team therefore decided in favour of distributing the obtainable profiles over the whole area (N.B. there are hardly any bathymetric data available for that shoreface area).

Sediment samples were collected along transects perpendicular to the coastline. Whenever possible, samples were taken on the dune crest, at the dune base and at the

high, mean and low tide water levels. Sediment samples were processed and analysed to determine grain size fractions (as described in Section 2.4).

Collected data were integrated in a Geographical Information System (GIS) for further spatial analysis, using the PT-TM06/ETRS89 (EPSG: 3763) coordinate system. To assess morphodynamics during the observation period, a different DEM was obtained for each campaign from terrestrial mobile mapping and from airborne photogrammetric surveys (Fig. 8). Contours, partial and total volumes and sediment budgets were determined for different topographic height classes, and for each of the coastal segments.

Survey results were used in combination with wave climate data (from the same close-by offshore directional wave buoy as in the previous study), and a local 


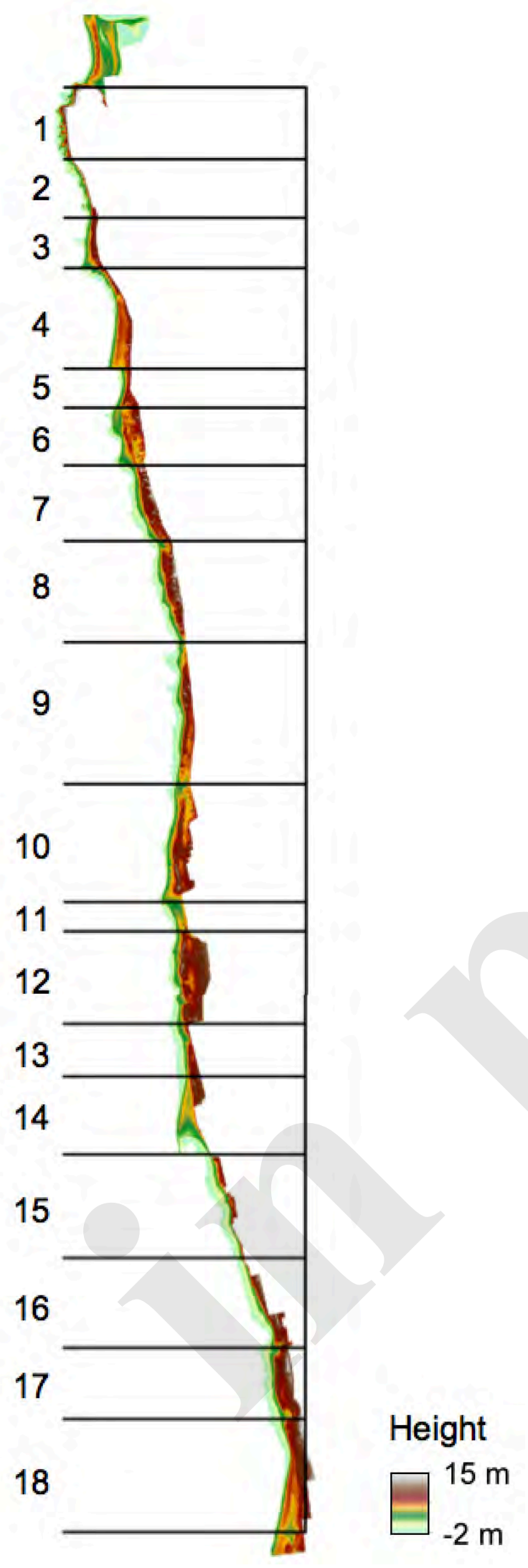

Figure 8 - DTM of the Vila Nova de Gaia coast for November 2008, obtained through photogrammetry, and the division of the coast into 18 segments.

Figura 8 - MDT da costa de Vila Nova de Gaia para Novembro de 2008, obtido por fotogrametria, e a divisão da costa em 18 segmentos. wave propagation model was implemented to assess local wave energy spatial distributions and produce erosion risk maps. Field data and model outputs were integrated, processed and analyzed to assess the coastal vulnerability to erosion and for the elaboration of associated risk maps using a multi-criteria assessment approach. A specific erosion risk assessment methodology was developed for this work, at the University of Minho, based on morphological, hydrodynamic and other indicators that were quantified using the data and results obtained from the monitoring program. Vulnerability and exposure indicators were aggregated in order to classify the coast according to three erosion risk classes - low, intermediate and high risk.

The applied methodology was based on previous works (Thieler \& Hammar-Klose, 1999; Thieler, 2000; Thieler

\& Pendleton et al., 2005; Rajawat et al., 2006; Hegde \& Reju, 2007; Loureiro, 2006; Kumar et al., 2010), but specifically adapted to the local characteristics of the coastal stretch under study. Comparing our methodology with the above cited, there are three main distinguishing aspects: (i) the segmentation for the quantifycation of indexes (susceptibility, exposure and risk) is also based on specific coastal types, obtained by a judicious delimitation based on the beach-dunes-urban front main characteristics, as well as human occupation and administrative boundaries; (ii) a new set of susceptibility variables is proposed, and others used in previous works (eg. tidal range; offshore significant wave height; mean sea level rise) are neglected since they showed almost uniform values along the whole studied coastal stretch, not adding information to the risk assessment; and (iii) the adopted exposure variables resulted from a detailed quantification of the existing building and beach areas extracted from the aerial digital photos.

In a first phase a base line was defined, delimiting areas that were strongly occupied from those that have some capability to adapt to the effects of natural forcing factors (mainly winds and waves). The area was divided into 47 elementary segments considering the coastal typology, administrative boundaries and human occupation. For each segment a set of susceptibility indicators was quantified: coastal segment average elevation; width and slope; volume rate computed according to two DEMs obtained in different times; a wave-energy related indicator computed using wave propagation model results; and the percentage of vegetated area. The area of existing buildings in a predefined buffer and the area occupied by sandy beaches in each segment were considered as exposure indicators. The erosion risk index was finally computed based on two partial indexes: the vulnerability index and the exposure index (Fig. 9).

Computation of each vulnerability and exposure indicators within each segment was supported by GIS tools using the relevant field data and DEM. Moreover, 
Susceptibility indicators
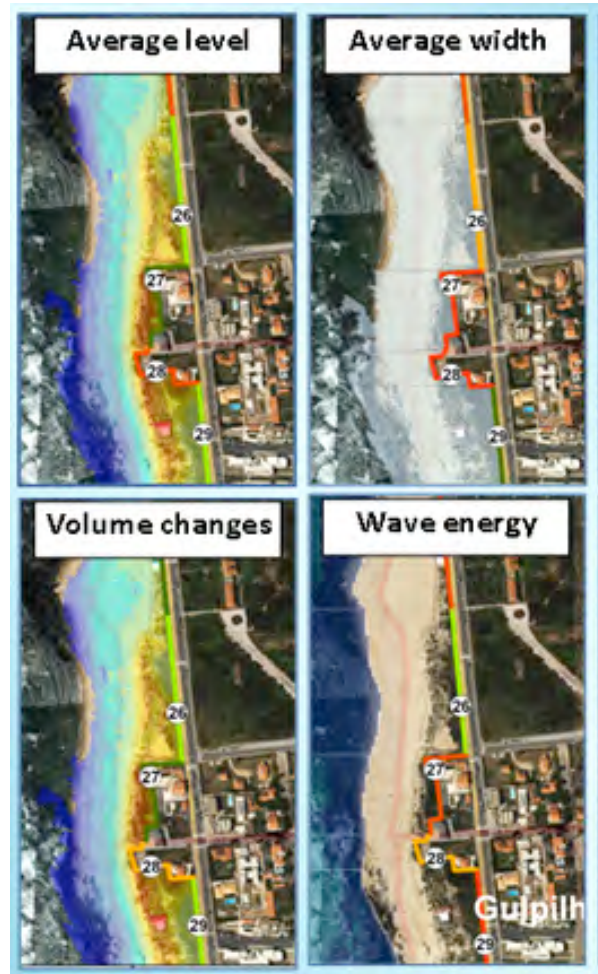

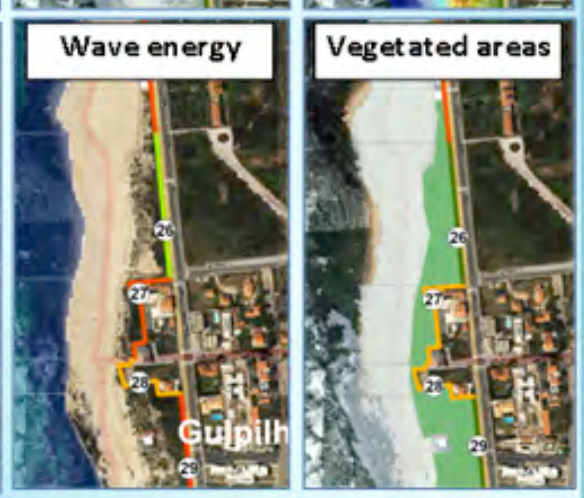

Exposure indicators

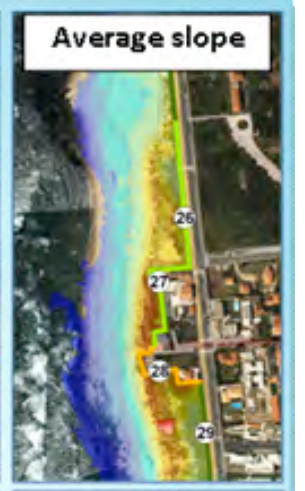

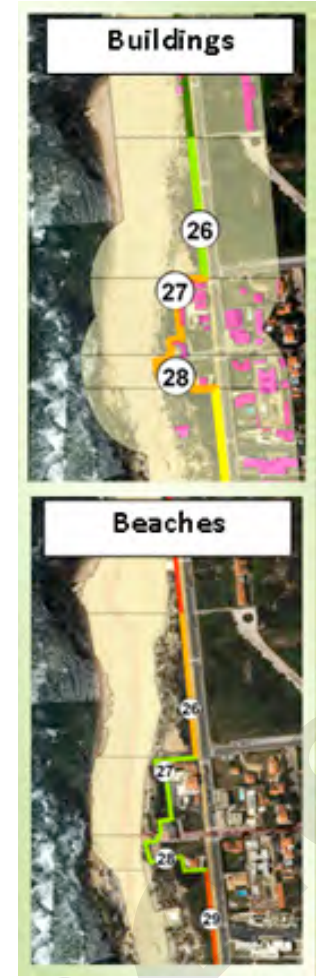

Erosion risk

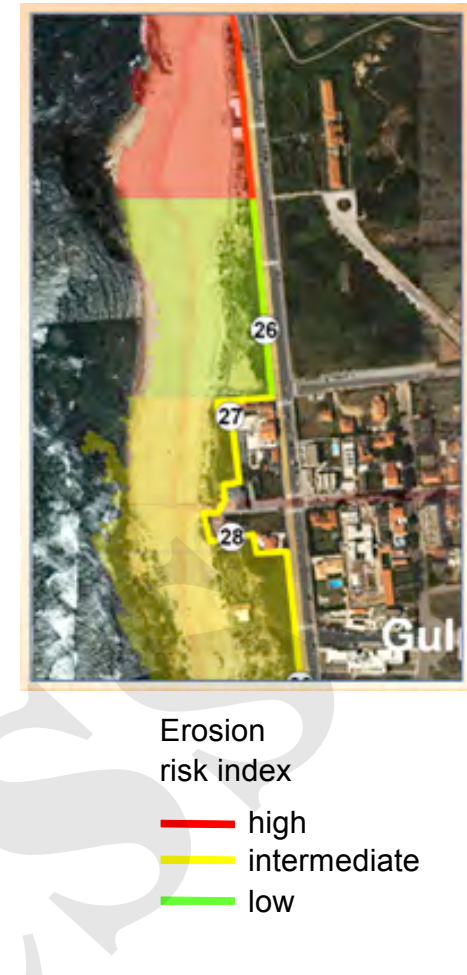

Figure. 9 - Vulnerability and impact indicators used for erosion risk analysis; a part of the coast by Gulpilhares is shown.

Figura 9 - Indicadores de vulnerabilidade e impacto utilizados na análise de risco de erosão; mostra-se uma parte da costa junto a Gulpilhares.

models were applied to analyse local wave propagation dynamics and estimate the susceptibility of the coast to a predefined wave event. This way, the model allows estimation of the wave energy near the coast (within a predefined buffer) resulting from the propagation of an offshore wave event.

Model simulation results were used to discriminate coastal segments in terms of susceptibility to wave action. Wave propagation was modelled at specific locations to identify local patterns useful for the understanding of the observed sedimentary dynamics (Granja $\&$ Pinho, in press). The numerical model used is based on a Boussinesq equations formulation (Nawogu \& Demirbilek, 2001) and is able to simulate most hydrodynamic phenomena that are of interest for coastal zones, such as: silting-up; refraction; diffraction; com-plete and partial reflection/transmission; bottom friction; non-linear wave-wave interactions; wave breaking; wave-induced currents; and wave-current interaction.

The model was integrated in a hydroinformatic environment appropriate for coastal processes modelling (Pinho, 2001). The bathymetry used in the model construction was derived from the combination of a coarse bathymetric database (from Instituto Hidrográfico, 2010) available for this coastal zone and the higher-resolution bathymetric data obtained with the ASV. Model results were processed in order to estimate the wave energy reaching each segment for a constant energy source at the offshore model boundary. This new approach allows assessing which coastal segments are most exposed to wave actions, mainly due to shoaling, diffraction and refraction phenomena.

\subsubsection{Results and discussion}

The Vila Nova de Gaia monitoring program allowed, for the first time, both a quantitative analysis of morphological changes and an erosion risk assessment for the whole coastal stretch of this municipality, which is characterized by small pocket beaches between rocky outcrops, generating tombolos and creating specific local and still poorly understood dynamics. This coastal area presents very diverse segments, with morphodynamic behaviour influenced by local hydrodynamics, sometimes conditioned by recent man-made structures (Granja \& Pinho, in press; Granja et al., 2011). Most segments have been suffering erosion, some show accretion, partially supported by artificial sand nourishment, e.g. at Granja Beach, where this sand however is rapidly lost. The observed erosion trends constitute a serious problem for this densely populated and build-up area, where the natural migration of the coastal system is severely restricted. Besides susceptibility to erosion, local ecological and economical values have to be considered and also evaluated. 
Considering the 18 administrative divisions of the studied coastal stretch (Fig. 8), evolutionary trends, based on the analysis of orthophoto-maps from 2005 (i.e. previous to the monitoring program) to 2009, showed erosion trends in segments 2, 3, 4 (northern part), 5, 9, 13, 15, 16, 17 and 18, and accretion trends in segments 4 (south), 11 (north) and 14. During this monitoring program $(2008 / 2010)$, in November 2008, recent erosion phenomena were observed for the segments 2 to 9, whereas segments 10 to 13 and the northern part of segment 14 were temporarily stable.

Two segments showed erosion due to man-made structures: segment 5, where a reinforced sewage pipe acts as a groin, affecting sediment circulation by the north-south drift and causing erosion south of the pipe; and segment 15 and part of sector 14, which have lost sediments due to the breakwater at Aguda Beach. The Aguda Beach breakwater had originally been planned as a detached breakwater to protect a small fishing harbour. But after some months, still during the works of the breakwater construction, a tombolo wedge beach formed against the temporary groin, promoting enlargement of the beach located up-drift and erosion at the down-drift coastal segment (Granja Beach). The temporary groin was not removed (Rosa-Santos et al., 2009) and the space between the breakwater and the harbour filled up, rendering the harbour useless (RosaSantos et al., 2009; Granja et al., 2011).

Between November 2008 and November 2009, segments 3, 5, 10 and 12 showed negative sedimentary budgets, and segments 5, 14 (south) and 15 (affected by the above mentioned structures) suffered marked erosion. Artificial beach nourishment with sand had positive, though very short-lived, effects on the Granja beach. Sedimentary budgets became more favourable by May 2010, with accretions observed particularly in the upper, dry and vegetated part of the beaches (affected by wind conditions), whereas the wet part of the beach (affected by waves and currents) showed erosion in the most vulnerable sectors.

Sedimentary analyses showed the presence of quite coarse sands, which are overall homogeneous in size class distribution, both alongshore and cross-shore, possibly related to artificial beach nourishment, with sediments coming from waste landfill sites. In later surveys, coarser sediments were hidden by finer ones, reflecting less ocean wave impact and fresh sediment supply. Sub-tidal surveys showed that beaches with low slope - both above and below the water line - were preferential accretion sites. Interpretation of the sonar data revealed accretion areas on the inner continental shelf (nearshore) and relationships between the morphodynamical behaviours of the nearshore and the contiguous foreshore.
The used complementary observation methods allowed:

(i) identification of particular morphodynamic processes (using field observations),

(ii) characterization of the nature of beach sediments (georeferenced sediment samples),

(iii) acquisition of high resolution beach mor-phology (MMS),

(iv) extension of the DEM to vege-tated and other sensitive areas (using the non-invasive aerial photogrammetric method), and

(v) characteriza-tion of the nearshore bottom (sub-tidal bathymetric surveys).

Through this holistic approach a set of relevant data was obtained, concerning the fundamental morphodynamic processes that occur in the studied coastal segments, resulting from wave and wind action as well as human interventions (coastal defence structures and dune fences), allowing erosion risk classification of the coastal segments according to the aggregated score of their vulnerability and exposure indexes (Fig. 10). Erosion risk is higher for southern areas, with northern areas presenting a mixed behaviour.

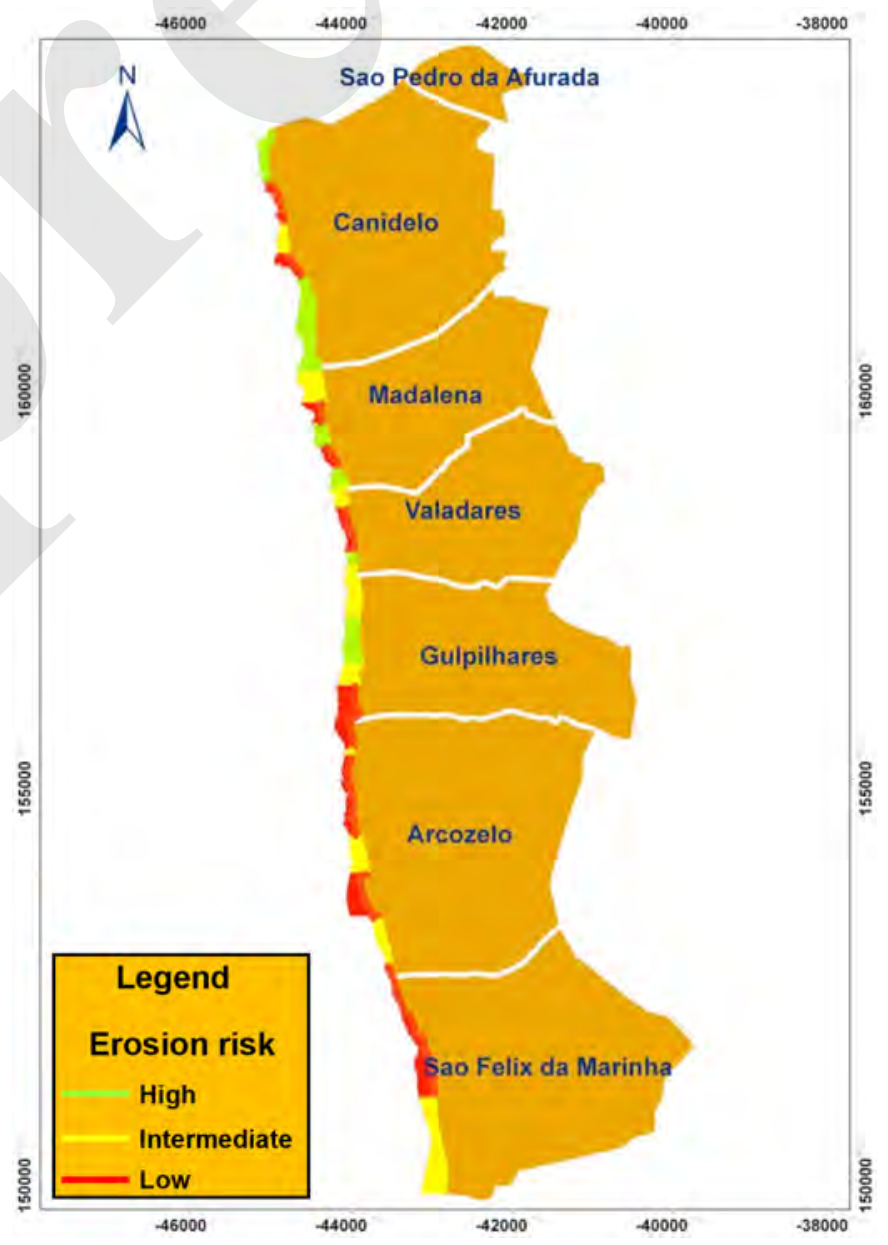

Figure 10 - Erosion risk map for the Vila Nova de Gaia coast.

Figura 10 - Mapa de risco de erosão para a costa de Vila Nova de Gaia. 


\section{Conclusion}

Coastal monitoring programs should be set up based on the specific objectives and on the characteristics of the area to be monitored. Selection of monitoring methods will obviously depend on type and accessibility of the area, on its size, and on the expected rates of change (fast changes may require more frequent, i.e. easier to deploy, monitoring). Availability of equipment and know-how will also influence the choice of methods. A cost-benefit analysis should help deciding whether it is, for instance, worth using the more expensive but faster and non-invasive aerial methods, or the more limited but more precise and cheaper terrestrial survey methods.

Topographic surveys should have a better than decimetre precision to be useful. Traditional point or crossshore profile surveys (with total station technique) have high precision but are very time and labour-intensive. The proposed terrestrial MMS methodology provides very precise $3 \mathrm{D}$ surveys (our precision of $5 \mathrm{~cm}$ is comparable to that of Harley et al., 2007) and is easier to apply, weather resistant and low cost. Deployment of the equipment is easy and fast, so that sudden changes, e.g. after severe storms, can easily be assessed (which is not the case when using traditional techniques). The main limitation of this method is the production of discrete spatial information, which is not very sensitive to small forms when compared with continuous data.

Topography based on aerial stereo high-resolution digital photography and photogrammetry is less precise but can provide spatially continuous data, important for an effective morphological assessment. Laser surveys constitute an alternative, but although they are more precise, they are currently extremely expensive. In comparison to terrestrial systems, aerial surveys are more expensive and the equipment is not as easily deployed. But they have other advantages: they are better suited for regional monitoring, as vast areas (tens of kilometres) can easily be observed in a few minutes; and, they are non-invasive. This is particularly important when monitoring ecologically sensitive areas, like vegetated dunes, or estuarine marshes. Ground vehicles have to access the site to operate. Aerial photography also captures fragmented terrains and observes the whole beach, including the intertidal region and features in the water, e.g. rocky outcrops.

Furthermore, the high-resolution images constitute a visual record of the study area, where vegetation, buildings and infrastructure can be located and quantified (through image analysis). Classification of, for instance, vegetation can be done taking advantage of the additional (though lower- resolution) red, green, blue and near-infrared image bands. The innovative (terrestrial) videogrammetric approach used in the presented case studies also provides a visual record of the area, where ground features such as dune vegetation are recorded. These records can be kept in GIS databases and be further analysed. Sub-tidal bathymetric and sonar surveys constitute an underwater extension of the surveyed area, which is important because the sediment types, structure and slope of the submerged area have a direct impact on the degree of erosion and stability of the contiguous foreshore, mainly due to cross-shore transport.

The presented case studies demonstrate the potential of several approaches, supported by advanced technologies, for the study of complex coastal morphodynamic processes. Both monitoring programs achieved their proposed objectives and provided valuable information to the local authorities, as gathered and processed information constitutes a valuable database for coastal planning and for ICZM purposes. The monitoring program for the Vila Nova de Gaia coast is particularly innovative as it combines several observation techniques in a systematic way, in sequential campaigns, providing information for a detailed analysis with a high spatial resolution. This combination allows a detailed and continuous observation in a coastal buffer delimited by the urban front and the outer shoreface. The relatively short length of the coastal stretch implies that other erosion risk assessment methodologies based on relatively rough data (e.g., wave climate variables, tidal characteristics, medium to long term coastline dynamics; Thieler, 2000; Kumar et al., 2010), would fail to distinguish between different segments.

\section{Acknowledgments}

We thank: the Administração dos Portos do Douro e Leixões (APDL) for the financial support of the data acquisition for Douro Estuary sand spit study; INAG and EDP for the supply of river data; the Parque Biológico de Gaia, SA. for the financial funding of the Vila Nova de Gaia coast monitoring between 2008 e 2010; and Paulo Baptista for his help in the collection and processing of the GPS data. This research was partially supported by the European Regional Development Fund (ERDF) through the COMPETE - Operational Competitiveness Programme and national funds through FCT - Foundation for Science and Technology, under the project "Pest-C/ MAR/LA0015/2013", and partially funded by the Project ECORISK (reference NORTE-07-0124-FEDER000054), co-financed by the North Portugal Regional Operational Programme (ON.2 - O Novo Norte), under the National Strategic Reference Framework (NSRF), through the European Regional Development Fund (ERDF). Wave climate analyses were supported by the FCT-funded RAP project (PTDC/MAR/111223/2009).

\section{References}

Archetti, R.; Zanuttigh, B. (2010) - Integrated monitoring of the hydro-morphodynamics of a beach protected by low crested detached breakwaters. Coastal Engineering, 57(10):879-891. DOI: 10.1016/j.coastaleng.2010.05.002

Baptista, P.; Bastos, L.; Bernardes, C.; Dias, J. (2008) - Monitoring sandy shores morphologies by DGPS - a practical tool to 
generate digital elevation models. Journal of Coastal Research, 24(6):1516-1528. DOI: $10.2112 / 07-0861.1$

Barnard, P.L.; Warrick, J.A. (2010) - Dramatic beach and nearshore morphological changes due to extreme flooding at a wavedominated river mouth. Marine Geology, 271(1-2):131-148. DOI: $10.1016 /$ j.margeo.2010.01.018

Bastos, L; Bio, A; Silva, J.; Pinho, J.L.S.; Granja, H. (2012) Dynamics of the Douro estuary sand spit before and after breakwater construction. Estuarine, Coastal and Shelf Science, 109:53-69. DOI: $10.1016 /$ j.ecss.2012.05.017

Boak, E.H.; Turner, I.L. (2005) - Shoreline definition and detection: A review. Journal of Coastal Research, 21(4):688-703. DOI: $\underline{10.2112 / 03-0071.1}$

Brilakis, I.; Fathi, H.; Rashidi, A. (2011) - Progressive 3D reconstruction of infrastructure with videogrammetry. Automation in Construction, 20(7):884-895. DOI: 10.1016/j.autcon.2011.03.005

Consulmar (1996) - Estudos das obras necessárias à melhoria da acessibilidade e das condições de segurança na barra do Douro. Consulmar Report, Administração dos Portos do Douro e Leixões (in Portuguese), Lisboa, Portugal. Unpublished.

Costa, M.; Silva, R.; Vitorino, J. (2001) - Contribuição para o Estudo do Clima de Agitação Marítima na Costa Portuguesa. Actas das 2as Jornadas Portuguesas de Engenharia Costeira e Portuária. Associação Internacional de Navegação, Sines, Portugal (in Portuguese). Available on-line at ftp://ftp.mohid.com/Fortaleza CD/Bibliografia/Waves/clima ag $\underline{\text { mar.pdf }}$

Cowart, L.; Walsh, J.P.; Corbett, D.R. (2010) - Analyzing Estuarine Shoreline Change: A Case Study of Cedar Island, North Carolina. Journal of Coastal Research, 26(5):817-830. DOI: 10.2112/JCOASTRES-D-09-00117.1

Cruz, J. (2008) - Ocean Wave Energy. Current Status and Future Perspectives. Green Energy and Technology. 431p., Springer, Berlin. ISBN 978-3-540-74895-3

Dail, H.J.; Merrifield, M.A.; Bevis, M. (2000) - Steep beach morphology changes due to energetic wave forcing. Marine Geology, 162(2-4):443-458. DOI: 10.1016/S0025-3227(99) 00072-9

Davidson, M.; Van Koningsveld, M.; de Kruif, A.; Rawson, J.; Holman, R.; Lamberti, A.; Medina, R.; Kroon, A.; Aarninkhof, S. (2007) - The CoastView project: Developing video-derived Coastal State Indicators in support of coastal zone management. Coastal Engineering, 54(6-7):463-475. DOI: 10.1016/ j.coastaleng.2007.01.007

Dodet, G.; Bertin, X.; Taborda, R. (2010) - Wave climate variability in the North-East Atlantic Ocean over the last six decades. Ocean Modelling, 31(3-4):120-131. DOI: 10.1016/j.ocemod. $\underline{2009.10 .010}$

Ferreira, H.; Almeida, C.; Martins, A.; Almeida, J.; Dias, N.; Dias, A.; Silva, E. (2009) - Autonomous bathymetry for risk assessment with ROAZ robotic surface vehicle. OCEANS 2009 IEEE Bremen, 1-6. Available on-line at http://wrem2012.isr. uc.pt/Papers/Ferreira_WREM2012.pdf

Fletcher, C.; Rooney, J.; Barbee, M.; Lim, S.C.; Richmond, B. (2003) - Mapping shoreline change using digital orthophotogrammetry on Maui, Hawaii. Journal of Coastal Research, SI38:106-124. Available on-line at $\mathrm{ftp} / / / \mathrm{ftp}$.soest.hawaii.edu /coastal/webftp/JCR MappingShoreline.pdf

Gonçalves, J.; Bastos, L.; Pinho, J.; Granja, H. (2011) - Digital aerial photography to monitor changes in coastal areas based on direct georeferencing. 5th EARSeL Workshop on Remote Sensing of the Coastal Zone, Prague, Czech Republic. http://www.conferences.earsel.org/abstract/show/2689
Granja, H.; Bastos, L.; Pinho, J.; Gonçalves, J.; Henriques, R.; Bio, A.; Magalhães, A. (2011) - Small harbours risks: lowering for fishery and increasing erosion. The case of Portinho da Aguda (NW Portugal). Littoral 2010, 09003, DOI: 10.1051/ $\underline{\text { litt/201109003 }}$

Granja, H.M.; Carvalho, G.S. (2000) - Inland beach migration ("beach erosion") and the coastal zone management (the experience of the northwest coastal zone of Portugal). Periodicum Biologorum, 102(suppl. 1):413-424.

Granja, H.; Pinho, J. L. (2012) - Coastal defense in NW Portugal: the improbable victory. In: Cooper, J.; Pilkey, H. (eds.), The Pitfalls of Shoreline Stabilization, pp. 251-266, Coastal Research Library, vol 3, Springer, USA. ISBN: 9789400741232. DOI: $10.1007 / 978-94-007-4123-2 \quad 15$

Granja H.; Pinho J. L. (in press) - A multi-criteria approach for erosion risk assessment using a new concept of spatial unit analysis, wave model and high resolution DEMs. In: Charles, J.; Finkl, W., Makowski, C. (eds.), Advances in Coastal and Marine Resources: Remote Sensing and Modeling. Coastal Research Library, Springer, USA. ISBN: 978-3319063256.

Harley, M.D.; Turner, I.L.; Short, A.D.; Ranasinghe, R. (2007) Monitoring beach processes using conventional, RTK-GPS and image-derived survey methods: Narrabeen Beach, Australia. In: Woodroffe, C.D.; Bruce, E.M.; Puotinen, M.; Furness, R.A. (eds.), GIS for the Coastal Zone: A Selection of Papers from CoastGIS 2006, pp. 151-164. University of Wollongong, Australia. ISBN 9781741281378

Hegde, A.V.; Reju, V.R. (2007) - Development of coastal vulnerability index for Mangalore coast, India. Journal of Coastal Research, 23(5):1106-1111. DOI: 10.2112/04-0259.1

Henriques, R. (2004) - SEDMAC/SEDPC: An application to support particle size analysis of unconsolidated sediments. 32nd International Geological Congress, Florence-Italy, abs. 154-6, p. 726.

Holland, K.T.; Vinzon, S.B.; Calliari, L.J. (2009) - A field study of coastal dynamics on a muddy coast offshore of Cassinobeach, Brazil. Continental Shelf Research, 29(3):503-514. DOI: 10.1016/j.csr.2008.09.023

Jacobsen, K. (2000) - User Manual Program System BLUH, 444p., Institute for Photogrammetry and Engineering Surveys, University of Hannover. Available via http://www.ipi.unihannover.de $/ \mathrm{kj} . \mathrm{html}$ ? \&L $=1$

Kumar, T.S.; Mahendra, R.S.; Nayak, S.; Radhakrishnan, K.; Sahu, K.C. (2010) - Coastal Vulnerability Assessment for Orissa State, East Coast of India. Journal of Coastal Research, 26(3):523-534. DOI: $\underline{10.2112 / 09-1186.1}$

Loureiro, E. (2006) - Indicadores geomorfológicos e sedimentológicos na avaliação da tendência evolutiva da zona costeira: aplicação ao concelho de Esposende. 329 p., PhD Thesis, Universidade do Minho (in Portuguese). Available on-line at http://hdl.handle.net/1822/7096

Madeira, S. (2007) - Sistema Móvel Terrestre de Levantamento com Integração em SIG. PhD Thesis, Porto University (in Portuguese). Unpublished

Madeira, S.; Gonçalves, J.; Bastos, L. (2009) - Fast Camera Calibration for Low Cost Mobile Mapping. Proceedings of the $6^{\text {th }}$ International Symposium on Mobile Mapping Technology (MMT09), 21-24 July 2009, Presidente Prudente, São Paulo, Brazil. Available on-line at http://docs.fct.unesp.br/departamentos/ cartografia/eventos/2009 MMT/ papers/303 Madeira MMT09.pdf

Madeira, S.; Gonçalves, J.A.; Bastos, L. (2010) - Photogrammetric mapping and measuring application using MATLAB. Computers and Geosciences, 36(6):699-706. DOI: 10.1016/j.cageo.2009.06.015 
Muehe, D. (2011) Erosão Costeira - Tendência ou Eventos Extremos? O Litoral entre Rio de Janeiro e Cabo Frio, Brasil/Coastal Erosion. Revista da Gestão Costeira Integrada, 11(3):315-325. DOI: $\underline{10.5894 / \mathrm{rgci} 282}$

Nawogu, G.; Demirbilek, Z. (2001) - BOUSS-2D: A Boussinesq Wave Model for Coastal Regions and Harbors. Report 1. Theoretical Background and User's Manual. US Army Corps of Engineers. Engineer Research and Development Center. USA. Available on-line at http://www.dtic.mil/cgi-bin/Get TRDoc?AD=ADA400294.

Nicholls, R.; Wong, P.; Burkett, V.; Codignotto, J.; Hay, J.; McLean, R.; Woodroffe, S.R.C. (2007) - Coastal systems and low-lying areas. In: Parry, M.; Canziani, O.; Palutikof, J.; Linden, P.V.D.; Hanson, C. (eds.) Climate Change 2007. Impacts, Adaptation and Vulnerability. Contribution of Working Group II to the Fourth Assessment Report of the Intergovernmental Panel on Climate Change. pp. 315-357, Cambridge University Press, Cambridge, U.K. ISBN 9780521 88010-7, Available on-line at https://www.ipcc.ch/ publications_and_data/publications_ipcc_fourth assessment_re port wg2 report impacts adaptation and vulnerability.htm

Niedermeier, A.; Romaneessen, E.; Lehner, S. (2000) - Detection of coastlines in SAR images using wavelet methods. IEEE Trans. Geoscience and Remote Sensing, 38(5):2270-2281. DOI: $\underline{10.1109 / 36.868884}$

Niesing, H. (2005) - EUROSION: Coastal erosion measures, knowledge and results acquired through 60 studies. In: Herrier, J.-L.; Mees, J.; Salman, A.; Seys, J.; Van Nieuwenhuyse, H.; Dobbelaere, I. (eds.), Proceedings 'Dunes and Estuaries 2005' International Conference on Nature Restoration Practices in European Coastal Habitats, pp. 421-431, Koksijde, Belgium, 19-23 September 2005, VLIZ Special Publication 19. Available on-line at http://ec.europa.eu/environment/life/project/Projects /index.

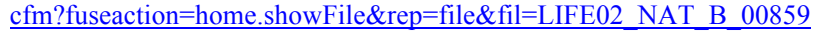
1 Seminar.pdf

Pendleton, E.A.; Thieler, E.R.; Williams, S.J. (2005) - Coastal Vulnerability Assessment of National Park of American Samoa to Sea-Level Rise. U.S. Geological Survey Open-File Report 2005-1055. Available on-line at http://pubs.usgs.gov/ of/2005/1055/images/pdf/report.pdf

Pereira, C.; Coelho, C. (2013) - Mapas de Risco das Zonas Costeiras por Efeito da Ação Energética do Mar. Revista da Gestão Costeira Integrada, 13(1):27-43. DOI: 10.5894/rgci325

Pinho, J.L.S. (2001) - Mathematical modelling application to hydrodynamics and water quality studies of coastal zones. $\mathrm{PhD}$ Thesis. University of Minho, Braga, Portugal (in Portuguese). Unpublished

Portela, L.I. (2002) - Plano específico de extracção de inertes do rio Douro: caracterização morfodinâmica do estuário do rio Douro. Report 215/02-NEC, 42p., LNEC, Lisbon, Portugal. (in Portuguese).

R Development Core Team (2009) - R: A language and environment for statistical computing. $\mathrm{R}$ Foundation for Statistical Computing, Vienna, Austria. ISBN 3-900051-07-0. Available on-line at http://www.R-project.org.

Rajawat, A.S.; Bhattacharya, S.; Jain, S.; Gupta, M.; Jayaprasad, P.; Tamilarasan, V.; Ajai; Nayak, S. (2006) - Coastal Vulnerability
Mapping for the Indian Coast. Second International Symposium on Geoinformation for Disaster Management.

Rasmussen, D.J.; Holloway, T.; Nemet, G.F. (2011) - Opportunities and challenges in assessing climate change impacts on wind energy - a critical comparison of wind speed projections in California. Environmental Research Letters, 6, 9pp. DOI: 10.1088/1748-9326/6/2/024008.

Rieke-Zapp, D.H.; Nearing M.A. (2005) - Digital Close Range Photogrammetry for Measurement of Soil Erosion. The Photogrammetric Record, 20(109):69-87. DOI: 10.1111/j.14779730.2005.00305.x

Rocha, C. P.; Araújo, T.C.M.; Mendonça, F.J.B. (2009) - Aplicação de metodologia alternativa para localizar e monitorar linhas de costa usando técnicas de posicionamento pelo GNSS: Um estudo de caso na praia de Sauaçui, Nordeste do Brasil. Revista da Gestão Costeira Integrada, 9(1):93-108. DOI: $10.5894 / \mathrm{rgci} 151$

Rosa-Santos P., Veloso-Gomes F., Taveira-Pinto F., Silva R., Pais-Barbosa J., 2009. Evolution of Coastal Works in Portugal and their Interference with Local Morphodynamics, Journal of Coastal Research, Special Issue 56:757-761. Available on-line at http://www.cerf-jcr.org/images/stories 1757.761 P.Rosa-Santos ICS2009.pdf

Short, A.D.; Trembanis, A.C. (2004) - Decadal scale patterns in beach oscillation and rotation Narrabeen Beach, Australia time series, PCA and wavelet analysis. Journal of Coastal Research 20(2):523-532. DOI: 10.2112/15515036(2004)020[0523:DSPIBO]2.0.CO;2

Silva, A.J.R.; Abecasis, C.; Leitão, J.C. (2005) - Improving the navigability and safety conditions in Douro estuary inlet. In: Smith, J.M. (ed.) Coastal Engineering 2004, 19-24 September 2004, vol 3. pp. 3277-3289, World Scientific, Singapore. ISBN: 978-981-256-298-2

Soares de Carvalho, G.; Granja, H.; Costa, A.L. (2006) - Dois casos de mudanças antrópicas na faixa costeira (praias e dunas) do noroeste de Portugal (segmentos costeiros de Leça da Palmeiraestuário do Douro e de Aguda-Espinho). Geonovas 20:13-25.

Souza, C.R. de G.; Luna, G. da C. (2010) - Variação da linha de costa e balanço sedimentar de longo período em praias sob risco muito alto de erosão do município de Caraguatatuba (Litoral Norte de São Paulo, Brasil). Revista da Gestão Costeira Integrada 10(2):179-199. DOI: $10.5894 / \mathrm{rgci176}$

Thieler, E.R., 2000. National Assessment of Coastal Vulnerability to Future Sea-Level Rise. USGS Fact Sheet, fs-076-100. Available on-line at http://pubs.usgs.gov/fs/fs 76-00/fs076-00.pdf

Thieler, E.R.; Hammar-Klose, E.S. (1999) - National Assessment of Coastal Vulnerability to Sea-Level Rise: Preliminary results for the U.S. Atlantic Coast. U.S. Geological Survey Open-File Report 99-593. Available on-line at http://pubs.usgs.gov/of/ $\underline{1999 / \text { of } 99-593 /}$

Zhu, Z.; Brilakis, I. (2009) - Comparison of optical-sensor-based spatial data collection techniques for civil infrastructure modelling. Journal of Computing in Civil Engineering, 23(3):170-177. DOI: $10.1061 /(\mathrm{ASCE}) 0887-3801(2009)$ $\underline{23: 3(170)}$ 
Bio et al. (2014) 